\title{
Critical Thinking of Field Independent Students; which Model of Teaching is more Supportive?
}

\author{
Nurnia $^{1}$, Herlina Anggaraini Tasina ${ }^{2}$
}

\section{Info Artikel}

Sejarah Artikel: 12 juni 2020

Diterima: 18 Juni 2020

Direvisi: 22 Juli 2020

Dipublikasikan: Agustus 2020

e-ISSN: 2620-3081

p-ISSN: 1411-2744

DOI:10.21009/jtp.v22i2. $\underline{16018}$

\begin{abstract}
This study examines whether a certain learning condition as of model of teaching is more supportive to the enhancement of critical thinking of field independent students. To be brief is that whether students with cognitive style of field independent function more superior through particular implemented models of flipped classroom, pure online or direct instruction. The study was a quasi-experiment conducted to 96 English majors divided equally in three different classes and treated with a different model. Data were collected by asking samples to take a critical thinking skills test after the treatment. Data were analyzed by means of two-way analysis of variance. Findings of the study show that the critical thinking skills of field independent students differ significantly after the three models implementation and the flipped classroom model is found to be more supportive.
\end{abstract}

Keyword: critical thinking, field-independent, flipped classroom, pure online, direct instruction

(C) 2020 PPS Universitas Negeri Jakarta

\section{INTRODUCTION}

Critical thinking has been the main issue in every aspect of life so as to be called as a life skill. Someone who always thinks critically will be more easily to solve a problem and can foster a new innovation. By thinking critically, one can consider information, assess conclusions and make correct conclusions (Christen \& Angermer, 1994). Critical thinking skills are needed to support one's life now and in the future economically, socially and culturally (Hayat \& Yusuf, 2010).
While critical thinking skills are of necessity to master, researches show that not many students have mastered the skills. A survey

${ }^{1}$ FKIP, Halu Oleo Univeristy, Kendari Sulawesi Tenggara, nurnia.68@ ${ }^{2}$ SMPN 5 Kendari, Kendari Sulawesi Tenggara, herlinamelay@gmail.

of every thousand people having an interest in reading. The results of PISA in 2015 reported that $55 \%$ of 15 -year-old students cannot recognize the main idea, understand or interpret the meaning of a reading text $(\mathrm{OECD}, 2016)$ meaning more than half of Indonesian students do not have the basic ability to think critically.

Having the aforementioned condition, language educators such as those in higher 
education need to find ways on how to help students possess the skills. Some believe that critical thinking could be developed through a particular learning condition such as through online platform to practice real life condition in this disruptive era. Roberston et.al. (2005) observed that online learning can improve students' thinking skills and learning achievement and are more satisfying than face-to-face or direct learning. Kharat et al. (2015) observed that Flipped Classroom can develop higher-order thinking skills because students can engage in active learning, interact with friends and lecturers, and use the knowledge they have learned to analyze, synthesize, apply their knowledge to evaluate, build, design and create new thing. Meanwhile, direct learning is seen as effective in teaching students to remember facts or understand concepts, while active learning such as learning activities with friends and problem-based (Bishop \& Verleger, 2013) benefits the development of high-level cognitive processes (Hamdan, McKnight, McKnight, \& Arfstrom, 2013). Therefore. this study is aimed to examine whether field independent students differs significantly in their critical thinking after being exposed to three different models of teaching. This study is of essential to see whether the said students are always relevant to develop their critical thinking no matter what models of teaching they are involved in or whether such students need more freedom or self-study through the use of technology to independently develop their critical thinking.

\section{Critical Thinking}

Critical thinking is related to the use of mental skills or cognitive strategies that increase the likelihood of getting the desired results. Various definitions have been proposed by experts. Critical thinking is reflective and reasoned thinking that emphasizes deciding what is believed and what is not (Ennis (1993). Critical thinking is the process of determining the authenticity, accuracy, and importance of information or knowledge in the meantime (Perdamean, 2012). Based on these definitions, we can draw the conclusion that critical thinking is a self-assessment carried out consciously and with a clear purpose in making interpretations, analyzes, evaluations and conclusions, and also provides an explanation on the basis of consideration of evidence, concepts, methods, criteria and context on which to base an assessment.

Experts have developed various concepts about the scope of critical thinking skills. Bloom (1978) revealed that thinking skills must be emphasized in problem solving, application of principles, analysis and creativity which are realized into the higher order thinking skills of his cognitive taxonomy such as analysis, evaluation and creativity. Ennis and Norris (1990) suggested that critical thinking skills are grouped into 5 steps, namely: (1) providing simple explanations, (2) building basic skills, (3) concluding, (4) providing further explanation, and (5) organizing strategy and tactics. Meanwhile, experts in teaching and evaluating education have made consensus and decided on six main critical thinking skills, those are interpretation, analysis, drawing conclusions, evaluation, explanation and self regulation (Facione, 2015). In this study, we 
applied the latter six skills by Facione (2015) since the skills comparatively cover all concepts proposed by all aforementioned experts. In addition, this category has also included selfregulation which does not well occupied in Bloom's category but might be similar to the skill of organizing strategy and tactics in Ennis and Norris's (1990) term.

\section{Field Independent (Cognitive Style)}

Simply stated, cognitive style is the process of how individuals receive and process information. Some experts have provided concuring definitions. Witkin, et.al. (1971) defines cognitive style as a form of displacement in a unique and consistent way that is displayed in one's perceptual and intellectual activities. Messick, et.al. (1976) explains that cognitive styles as attitudes, preferences and strategies are used by individuals in remembering, thinking and solving problems. Furthermore, Riding and Cheema (1991) interpret cognitive style as an individual's way of solving problems, thinking, feeling and remembering. To conclude, cognitive style is a consistent tendency and individual characteristics in receiving, remembering, organizing, and processing information and solving problems.

Witkin et.al. (1976) maintains that every individual has their own way of managing and processing information. This means that each individual has a cognitive style that is different from one another. To concur, Kozhevnikov (2014) emphasises that cognitive style represents differences in the cognition of each individual in overcoming their environment. In this regards, Witkin et.al. (1976) identified individuals on two different sides as analytic (Field independent) or global (Field dependent). In this study, we examine specifically how the field independent students develop their critical thinking. Students who have this tendency might approach the environment in an analytical way, that is, separating information separately from its broader part, for example, distinguishing images as the smallest part of the background or the largest part. According to Saracho and Spodek (1981), field independent individuals have the ability to decipher abstract items and solve problems in different contexts, are actively task oriented, have analytic skills, and enjoy working independently. In line with this, Garger and Guild (1984) states that these individuals perceive information analytically, developing concepts specifically, individually, independently, and motivated from within themselves. To concur, research by Kannan (1996) shows that individual differences lie in the way they process information. Thus, cognitive style is an important factor to investigate since it might affect the way of learning and the way students interact with lecturers and other classmates.

\section{Models of Teaching}

In general term, modes of teaching could be categorized into three ways that is with the use of digital technology or without which and/or with the combination between the two. As such, nowadays we come to know about the purely online learning, the blended learning and the direct instruction or face-to face classroom. These modes of teaching have their own characteristics and advantages which might be appropriately used to certain condition of learning and learners. 


\section{Pure Online}

Purely online learning is a type of distance education whereby instructors and students are physically separated while the learning process and material are delivered via the internet (Clark, 2008). Clark (2008) states that learning is called online if $51 \%$ or more of the learning process is delivered online. As for pure online is an online instruction whereby the whole or most of the learning materials and instructional activities are delivered via internet or online platform and has no face-to-face classroom meetings.

Online learning in universities has often been found either in a blended or full (pure / fully online). Warbington (2001) observed that the use of the internet has provided many benefits so that universities now use distance learning technology. Students and lecturers use internet technology as a medium or source of learning. With online learning, classes become more fun and effective because they provide wider opportunities for students to get learning materials online at unlimited times and places. Klimova and Poulova (2013) observed that students were basically open/receptive to online learning either in total or in mixture. Several reasons related to the benefits that can be obtained through the learning model. By studying the material online, students can complete the learning process in constructing knowledge that cannot be completed in class. In addition, those who cannot do it directly in class can access their lessons online outside the classroom / home at any time. Furthermore, if they do not understand the lesson while in class, they can get in touch with the instructor online to ask about it.

\section{Flipped Classroom}

Flipped Classroom is a type of blended learning where lecture sessions and homework sessions are reversed. In other words, tasks or exercises that are usually done at home are done at school; meanwhile, teaching or explaining lecture material that is usually done in class is given as homework through ICT-based and nonICT based learning in the form of video lectures, reading assignments or other lecture methods such as articles, books, power points or dictates. With this model, students will study the material before the lecture meeting. Every student who reads the material before lecturing will be easily invited to discuss or express opinions and deficiencies in their learning. Tucker (2012) states that meaningful learning in Flipped Classroom occurs as a result of using extra class time.

As a blended learning model, Flipped Classroom develops from the benefits or strengths of direct and online learning. First, collaboration learning environments both inside and outside the classroom encourage interaction between friends and make them learn from one another, which in turn forms a learning community. These activities encourage students to develop critical thinking skills and improve their learning process. Secondly, this model allows students to study learning material before meeting in class and achieve progress in learning and allows the learning process according to their learning styles and abilities (Bergmann and Sams, 2012). Third, it can create more time for teachers to interact with students both individually and in groups; thus lecturers better understand learning needs and provide appropriate assistance. Fourth, lecturers 
provide flexibility and freedom to students so they can learn from activities designed to develop problem-solving skills (Flores, et.al., 2016).

\section{Direct Teaching}

The term Direct Instruction (face to face) has been used by many researchers as a learning pattern that includes activities such as instructors explaining new concepts, testing their understanding by practicing under the direction of the instructor (controlled exercises) and encouraging them to do exercises under the guidance of the instructor (guided practice) (Joyce et.al., 2015). Simply put, Direct Instruction (face to face) can be characterized by the delivery of material by the instructor, followed by the provision of guided exercises in class and the provision of independent assignments related to the topic to be done at home. Direct Instruction is a learning model that emphasizes the interaction between instructors and students (Magliaro et al., 2005) which is carried out in a guided manner based on regular learning sequences (Engelmann et al., 1998).

This model was created by Engelmann and colleagues in the 1960s at Illionois University in Champagne-Urbana under the Follow Through Grant project (Magliaro et.al., 2005). Engelmann et.al. (1988) reported that Direct Instruction which he designed was first implemented in 1968 in 12 schools in America through the DISTAR program and several other programs implemented in the 1970s. The program aims to improve learning efficiency by emphasizing effective presentation techniques by following pre-programmed learning material.

\section{METHOD}

The study method applied a quasiexperiment. Three parralel experimental classes were given different treatment. The first class was treated with a pure online model and the second with a flipped classroom model; as for the third was treated with a direct instruction model.

\section{Population}

This study was conducted at the University of Halu Oleo and took samples from undergraduate English majors. Samples consisted of 96 enrollees in a reading course during their second year in the university. The enrollees were seated into three different classes with an equal number of 32 per class, each attending a different model.

The pure online learning model was implemented through online meeting whereby the students did all the learning activities such as listening to lectures, participating in discussion and doing tasks through online platform (Edmodo). The second model was implemented by combining the online platform and face to face meetings whereby they firstly got accessed to the platform before class to watch video lectures, to take notes and to fill out quizzes and then attended classroom session to participate in the discussion with a lecturer and other students to review the materials from online session and then perform task completion. The last model was implemented in classroom whereby the students listened to lectures, participating in discussion, and working on some exercises. At the end of the meeting, the students were assigned with some tasks to be done at home. 
The teaching materials used in the study included six core critical thinking skills on how to interpret, analyze, evaluate, make inference, explain and self regulate towards authentic reading texts. These materials were presented to students through online video or face-to-face lecture relative to the teaching model implemented. Other materials included English reading texts and critical thinking skills exercises. The instrument employed in this study was a 6question essay test by which students were asked to firstly read several reading texts and then to answer critical thinking questions following each text. The test validity was established by a panel of experts with expertise in critical thinking and language skills. As for its reliability yielded a coefficient of 0.88 subjected to Cronbach's Alpha.

A two-way analysis of variance was used to test the hypothesis of no difference in performance among the groups. An alpha level of .05 was used in testing the hypothesis. The data were analyzed with the SPSS.

The analysis technique used to test the hypothesis of the influence of independent variables on the dependent variable is the Two Way Anova (Hair, 2010) and Post Hoc Test (Tuckey) (Garson, 2012). The data analysis of this study is by means of Statistical Package for Social Science (SPSS) version 16 for windows (Santoso, 2014) and Microsoft Excel for manual analysis.

\section{RESULT AND DISCUSSION}

Results

This study shows some results in terms of decriptive statistics and inferencial statistics. The descriptive statistics of the field independent students' critical thinking skills is shown as in Table 1.

Tabel 1. Descriptive Analysis of Field Independent Students' Critical Thinking Skills

\begin{tabular}{|l|l|l|l|}
\hline & $\begin{array}{l}\text { Pure } \\
\text { Online }\end{array}$ & $\begin{array}{l}\text { Flipped } \\
\text { Classroom }\end{array}$ & $\begin{array}{l}\text { Direct } \\
\text { Instruction }\end{array}$ \\
\hline Mean & 66.49 & 77.08 & 63.19 \\
\hline $\begin{array}{l}\text { Standar } \\
\text { Deviation }\end{array}$ & 14.193 & 11.698 & 11.452 \\
\hline Minimum & 47 & 58 & 44 \\
\hline Maximum & 92 & 94 & 83 \\
\hline Range & 44 & 36 & 39 \\
\hline
\end{tabular}

Based on the results of descriptive calculations as shown in Table 1, we can compare the different scores obtained by FI students in each model of teaching. FI students who were taught with the Flipped Classroom model got the highest mean score, maximum and minimum scores; those taught with the Pure Online come second and those with the Direct Instruction got the lowest. Meanwhile, the Pure Online model have the highest standard deviation of 14,193; whereas in Flipped Classroom and Direct Instruction (face to face) in a row are 14,193 and 11,452. These results indicate that the standard deviation of the Direct Instruction (face to face) model has the smallest range followed by Flipped Classroom and Pure Online.

This study uses the Two-way Anova to test the research hypothesis. Before testing the hypothesis, the data were tested for their normality and homogeneity at each factorial design cell. The test shows the significance values calculated both in the Kolmogorov-Sminov and Shapiro-Wilk columns with p-values (sig) greater than alpha $(\alpha=0.05)$ in all cells. In the Flipped Classroom a significance value of 0.163 was obtained in the Kolmogorov-Sminov column and 0.359 in the Shapiro-Wilk column. Because the 
sig value $>0.05$, the critical thinking skills data in the Flipped Classroom group is normally distributed. Similarly, the significance value in the next cells showed a significance value $>0.05$. It can be concluded that all data in all cells are normally distributed. The homogeneity of variants between groups was tested by using Bartlett test. The results of the analysis obtained Chi-Square value (X2count) of 9.458 which was lower than $\mathrm{X} 2$ tabel of 18.307. It is concluded that the three data sets had homogeneous variant. Thus, the data requirements for variance analysis were met.

The inferencial statistics examines whether the three groups differ significantly in the scores of their critical thinking skills. The result shows as in Table 2.

Table 2. Conclusion of HSD Test (Tuckey)

\begin{tabular}{|c|c|c|c|c|c|c|}
\hline \multirow{3}{*}{$\begin{array}{l}\text { Grou } \\
\text { ps } \\
\text { Grou } \\
\text { p } 1 \\
\& 2\end{array}$} & \multirow{2}{*}{\multicolumn{3}{|c|}{ Mean Difference }} & \multicolumn{2}{|c|}{$\begin{array}{l}\text { Critical } \\
\text { Score } q\end{array}$} & \multirow{2}{*}{$\begin{array}{l}\text { Conclu } \\
\text { sion }\end{array}$} \\
\hline & & & & $\begin{array}{l}0 . \\
05\end{array}$ & $\begin{array}{l}0 . \\
01\end{array}$ & \\
\hline & $\begin{array}{l}7 \\
7 . \\
0 \\
8\end{array}$ & $\begin{array}{r}6 \\
-\quad 6 . \\
4 \\
1\end{array}$ & $\begin{array}{r}10 \\
.6 \\
77\end{array}$ & $\begin{array}{l}10 \\
.3 \\
3\end{array}$ & $\begin{array}{l}12 \\
.9 \\
1\end{array}$ & $\begin{array}{l}\text { Group } \\
1 \\
\text { Group } \\
2\end{array}>$ \\
\hline $\begin{array}{l}\text { Grou } \\
\mathrm{p} \\
\& 3\end{array}$ & $\begin{array}{l}7 \\
7 . \\
0 \\
8\end{array}$ & $\begin{array}{r}6 \\
-\quad 3 . \\
1 \\
9\end{array}$ & $\begin{aligned} & 13 \\
& .8 \\
& 89\end{aligned}$ & $\begin{array}{l}10 \\
.3 \\
3\end{array}$ & $\begin{array}{l}12 \\
.9 \\
1\end{array}$ & $\begin{array}{l}\text { Group } \\
1 \\
\text { Group } \\
3\end{array}$ \\
\hline $\begin{array}{l}\text { Grou } \\
\mathrm{p}_{2} \\
\& 3\end{array}$ & $\begin{array}{l}6 \\
6 . \\
4 \\
1\end{array}$ & $\begin{array}{r}6 \\
-\quad 3 . \\
1 \\
9\end{array}$ & $\begin{aligned} & 3 . \\
& 21 \\
& 18\end{aligned}$ & $\begin{array}{l}10 \\
.3 \\
3\end{array}$ & $\begin{array}{l}12 \\
.9 \\
1\end{array}$ & $\begin{array}{l}\text { Group } \\
2 \\
\text { Group } \\
3\end{array}=$ \\
\hline
\end{tabular}

Group 1 = Flipped Classroom, Group 2 = Pure Online, Group 3 = Direct Instruction

The results of comparisons between models of teaching can be shown through the results of the Tuckey HSD test. Table 2 shows that the average of the students' critical thinking skills for the Flipped Classroom is 10.677 points higher than Pure Online (Group 1> Group 2) and 13.889 higher than Direct Instruction (Group 1> Group 3). However, that for the Pure Online is not different from that for the Direct Instruction (Group $2=$ Group 3), even though the average for the first was slightly higher or 3.2118 than the latter). To conclude, there is a significant difference between the critical thinking skills of the independent field students taught with the Flipped Classroom and those of the other two models (Pure Online and Direct Instruction). As for comparing between the Pure Online and the Direct Instruction, a significant difference is not obvious in the students' critical thinking skills.

\section{CONCLUSION}

Briefly, this study found that there are significant differences in critical thinking skills between students being taught with varied teaching models such as Flipped Classroom, Pure Online and Direct Instruction (face to face). This suggests that variations occuring in the critical thinking skills of Field Independent students are determined by differences in the application of the teaching models. From the comparison of the three models, Field Independent students on the Flipped Classroom model have significantly higher critical thinking skills than the other two models. In the Flipped Classroom model, Field Independent students are greatly advantaged by combining the use of technology and also face-toface meetings in real class as well as with the concept of class being reversed. While it is expected that Field Independent students also might achieve better in Pure Online learning condition, it is not a fact. Their not taking optimum advantages from internet technology 
might due to several possibilities such as lack of activation of learning independence among students and level of difficulty of critical thinking skills concept which still highly require direct scaffolding/ lecturer presence as in the flipped classroom. Technical issue relating to inadequacy of internet access for students to freely explore their online practices might become an issue. Therefore, it is of necessity to ensure the provision of such facilities if we are to fully support a pure online class. With flipped classroom, the students develop their learning capacity within two mode of delivery that is through face-to-face classroom interaction and online activities. In addition, the concept of flipped class which reverses the learning of lower and higher level of thinking has been proven to facilitate learning goals attainment. Having said that, it is justifiable that the students' critical thinking skills vary from among the different models of teaching. Additionally, the critical thinking skills of the students are found to be more effective when they are taught through the flipped classroom model. Thus, it is suggested that flipped classroom is to be used to develop critical thinking skills of the English majors.

\section{REFERENCES}

Bates, A. W. \& Poole, G. (2003). Effective Teaching with Technology in Higher Education: Foundations for Success. Jossey-Bass, An Imprint of Wiley. ERIC.

Bergmann, J., \& Aaron, S. (2012). Flip your classroom: Reach every student in every class every day. Washington, D.C: International Society for Technology in Education.

Bishop, J. L., \& Verleger, M. A. (2013). The Flipped Classroom: A Survey of the Research. 120th American Society for
Engineering Education Annual Conference and Exposition, 30, 1-18.

Bloom, B. S. (1978). New views of the learner: Implications for instruction and curriculum. Educational Leadership, 35(7), 563-576.

Christen, Richard and James Angermeyer. (1994). Performance Assessments of Critical Thinking: The Reflective Judgment Approach. University of Minnesota: College of Education.

Clark, T. (2008). Online Learning: Pure Potential. Educational leadership: journal of the Department of Supervision and Curriculum Development, N.E.A, 65(8), 1-6.

Engelmann, S., et.al. (1988). The Direct Instruction Follow Through Model: Design And Outcomes. Education and Treatment of Children, Vol. 11(4), 303-317.

Ennis, R.H., and Norris, S.P. (1988). CT Testing and Other CT Evaluation: Status, Issues, and Needs in Algina, J. (Ed), Issues in Evaluation, New York: Ablex Press.

Ennis, R.H. (1993). Critical Thinking Assessment. Theory into Practice, Vol. 32(3), 179-186. doi: 10.1080/00405849309543594

Facione, P.A. (2015). Critical Thinking: What It Is and What It Counts. Hermosa Beach, CA: Measured Resources. https://www.student.uwa.edu.au/_data/as sets/pdf_file/0003/1922502/CriticalThinking-What-it-is-and-why-itcounts.pdf

Flores, O., et.al. (2016). The flipped classroom model at the university: analysis based on professors' and students' assessment in the educational field. International Journal of Educational Technology in Higher Education, 13(2), 1-12. doi: 10.1186/s41239-016-0022-1.

Hamdan, N., et.al. (2013). A Review of Flipped Learning. Flipped Learning Network.1-20, doi: 10.4236/ce.

Hayat, B. \& Yusuf. S. (2010). Benchmark Internasional Mutu Pendidikan. Jakarta: PT Bumi Aksara.

Joyce, Bruce., et.al. (2015). Models of Teaching. Edisi 9. United States of America: Pearson Education, Inc. 
Kannan, S. (1996). Perhubungan Gaya Kognitif, Tahap Kognitif dan Pencapaian Fizik Pelajar Tingkatan Empat Sains. Jurnal Pendidikan.

Klimova, B.F. \& Petra Poulova. (2013). Analysis of Online Materials and their Impact on Learning. Computer Science: University of Hradec Kralove.

Kharat, A.G., et.al. (2015). Flipped Classroom for Developing Higher Order Thinking Skills. Journal of Engineering Education Transformations, Vol. 23: special edition. doi: : 10.16920/ijerit/2015/v0i0/59541

Kozhevnikov, Maria., et.al. (2014). Cognitive Style as Emvironmentally Sensitive Individual Differences in Cognition: A Modern Synthesis and Applications in Education, Business, and Management. Psychological Science in the Public Interest, 15(1), 3-33. doi: $10.1177 / 1529100614525555$

Magliaro, S.G., et.al. (2005). Direct Instruction Revisited; A Key Model for Instructional Technology. Educational Technology Research and Development, 53(4):41-55. doi: 10.1007/BF02504684

Messick, S., aet.al. (1976). Individuality in Learning. San Francisco, California: JoseyBass Inc.

OECD. (2016). 'Programme for International Students Assessment (PISA) Results from PISA 2015.' https://www.bps.go.id/linkTableDinamis/v iew/id/1054.

Perdamean, B. (2012). Measuring Change in Critical Thinking Skills of Dental Students Educated in a PBL Curriculum. Journal of Dental Education, 76(4) 443-53, doi: : 10.1002/j.0022-0337.2012.76.4.tb05276.x.

Riding, R., \& Cheema, I. (1991). Cognitive Styles: an Overview and Integration. Journal of Educational Psychology, 11(34), 193-215. doi: $10.1080 / 0144341910110301$

Robertson, J. S., et.al. (2005). Is Online Instruction Perceived as Effective as Campus Instruction by Graduate Students in Education? Internet and Higher Education, 8(1), 73-86. doi: 10.1016/j.iheduc.2004.12.004
Saracho, O.N. \& Spodek, B. (1981). The Teacher's Cognitive Styles and Their Educational Implications. Educational Forum. 45(2), 153-159. doi: $10.1080 / 00131728109336066$

Siemens, G. (2015). MOOCs and Open Education around the World. Books edited by Curtis J.B., et.al.: Taylor and Francis.

Tanduklangi, A. (201). Pengaruh Dukungan Organisasi, Budaya Organisasi, PersepsiKemudahan dan Persepsi Manfaat terhadap Minat Mahasiswa Menggunakan Teknologi Pembelajaran Elekronik (ELearning). Unpublished dissertation: Pascasarjana Universitas Halu Oleo.

Tucker, B. (2012). The Flipped Classroom. Education Next. Accessed from https://www.educationnext.org/files/ednex t_20121_BTucker.pdf on June 31 2020.

Vygotsky, L.S. (1978). Mind in society: The development of higher psychological processes. Cambridge, MA: Harvard University Press.

Warbington, Rachel. 2001. The Advantages of Online Learning. Women in Business. 53 (6).

Witkin, H.A. (1976). Cognitive Styles in Academic Performance and in TeacherStudent Relations. Individuality in Learning. San Francisco, CA: Jossey-Bass. 